\title{
DETAILED DESIGN OF A FIBER GLASS BASED MEDIUM SCALE PLUG FLOW REACTOR FOR BIOGASIFICATION OF BIODEGRADABLE FOOD WASTE FOR RURAL AND URBAN INDIA
}

\author{
Jyothilakshmi. $\mathbf{R}^{\mathbf{1}}$, S. V. Prakash ${ }^{2}$ \\ ${ }^{1}$ Assistant Professor, Department of Mechanical Engineering, M. S. Ramaiah Institute of Technology, Bengaluru-54 \\ jyothirswamy@gmail.com \\ ${ }^{2}$ Professor and Head, Department of Mechanical Engineering, CMR Institute of Technology, Bengaluru \\ yagprash@hotmail.com
}

\begin{abstract}
Plug flow reactor vessel is a long narrow (typically a 2:1 ratio; 2 times as long as the width) insulated inside and heated tank made of reinforced concrete, steel or fiberglass with a gas tight seal cover to collect the biogas. These digesters operate at a mesophilic or thermophilic temperature range. Retention time is usually ranges between 15 to 20 days. Fiber Glass is the material used for construction of the digester tank. The methanogens (methane producing micro-organisms) can digest sugar, starch, fats, cellulose and proteins etc. Their digestive mechanism is similar to that of many other organisms, up to the point of converting the food into acetic acid. Methanogens convert acetic acid into methane and carbon dioxide. $\left(\mathrm{CH}_{3} \mathrm{COOH}=\right.$ $\mathrm{CH}_{4}+\mathrm{CO}_{2}$ ). They work optimally at the temperature of $38^{\circ} \mathrm{C}$ and a $\mathrm{pH}$ value of 7 . At this temperature and $\mathrm{pH}$, they can convert food waste into biogas within a cycle of about 24 hours. $1 \mathrm{~kg}$ (dry weight) of food waste yields about $1 \mathrm{~kg}$ (about 800 litres) of biogas. To get the same quantity of biogas from dung, one needs about $40 \mathrm{~kg}$ dung, and a fermentation period of about 20 days. The calorific value of biogas will be about $4000 \mathrm{kCal} \mathrm{per} \mathrm{kg}$. The waste material to be fed into a biogas plant should contain only biodegradable organic material. Other organic products like plastic, rubber, petroleum, hooves or wood cannot be digested by the methanogens. Introduction of any toxic or bactericidal material into the biogas plant would kill the methanogens and the system would stop producing methane. Increase in the population density of non-methanogenic organisms causes reduction in that of the methanogens, inhibiting the formation of methane.
\end{abstract}

Keywords: Plug Flow Reactor, Top Part, Bottom Part, Fiber Glass, Inlet Pipe

\section{INTRODUCTION}

Biogas is generated by the fermentation of organic matter including manure, sewage sludge, and municipal solid waste, under anaerobic (absence oxygen) conditions (1). Biogas consists of $66.5 \%$ Methane, $30.5 \%$ Carbon dioxide, $0.5 \%$ Oxygen and Nitrogen, $2.5 \%$ Water. A biogas plant is an anaerobic digester of organic material for the purposes of processing waste and concurrently generating biogas. Biogas plant is an alternative to burning dried animal dung as a fuel and can be used for the treatment of human waste (2). Other feedstock which can be converted includes kitchen waste, plant material, non-meat or grease foodwastes, and most types of animal excreta (3).

Since small scale unit are relatively simple to build and operate, biogas should be used directly for for cooking, heating, lighting and absorption refrigeration. Since both electricity generation and compression of gas (for storage or use in vehicles) uses large amount of energy for a small output of useful energy. This concept is well suited for "distributed" systems where waste is treated at the source, and sludge is also reused locally, to minimize transport cost and initial capital cost(4). Current study is aiming at this where biodegradable household waste will be treated at source and end product(biogas) can be effectively used which intern will be useful in two ways one is solid waste management and energy production at lesser cost(5).

\section{Design of the Plug flow Reactor:}

\section{Factors influencing the design}

$>$ The biogas plant is to be kept in houses. For this the plant should be small enough to fit in through the door and also should not consume too much space(6).

$>$ The plant should be strong enough to hold around $0.857 \mathrm{~m}^{3}$ (857litres) of slurry (Water and waste mixture).

$>$ The plant should be easy to transport from one place to another.

$>$ The gas should be collected in such a way that the area for collecting the gas is optimized.

$>$ There should be enough pressure built inside the plant for the gas to flow into the balloon built for collecting the gas.

$>$ The balloon should be large enough to accommodate the generated gas.

$>$ The gas flow from the balloon to the outlet should be continuous without any disruptions. 


\section{Terms used:}

F: Total force on the whole surface is $\mathrm{N} / \mathrm{m}^{2}$.

$\rho$ : The Mass density of water in $\mathrm{kg} / \mathrm{m}^{3}$.

g: The Acceleration due to gravity in $\mathrm{m} / \mathrm{s}^{2}$.

A: The Area of cross-section in $\mathrm{m}^{2}$.

h': Distance of centre of gravity of the area from frees surface of the liquid in metres.

M: Moment carrying capacity of the section or bending moment in kg-m.

$\mathrm{Z}$ : Section modulus.

b: Unit width in metres.

d: Depth or thickness in meters.

h: Height of the bottom plant.

\section{Formulae used:}

$\mathrm{F}_{1}=\rho g h \mathrm{~A}$.

$\mathrm{P}_{1=}$ F/A.

$\mathrm{F}_{2}=\rho g h^{\prime} \mathrm{A}$.

$\mathrm{h}^{\prime}=\mathrm{h} / 2$.

Volume $=$ Length X Base X Height.

$\mathrm{M}=\mathrm{IS} 3370$ constant $\mathrm{X}$ Unit length $\mathrm{X}$ volume of bottom.

$\sigma=\mathrm{M} / \mathrm{Z}=\mathrm{M} /\left(\mathrm{bd}^{2} / 6\right)$.

\section{Design And Calculations:}

\section{$>$ Base}

Force acting on the base of the plant:

$\mathrm{F}_{1}=\rho g h \mathrm{~A}$

$$
=1000 \times 9.81 \times 0.7 \times(1 \mathrm{X} 0.95)
$$

$$
=6523.6 \mathrm{~N}
$$

$$
=665 \mathrm{kgf}
$$

Pressure acting on the base:

$$
\mathrm{P}_{1}=\mathrm{F} / \mathrm{A} \ldots \ldots \ldots \ldots
$$$$
=6523.6 /(1 \mathrm{X} 0.95)
$$

$$
=6.867 \mathrm{kN} / \mathrm{m}^{2}
$$

\section{Side walls}

Force acting on the side walls of the plant:

$\mathrm{F}_{2}=\rho \mathrm{gh}^{\prime} \mathrm{A}$

$\mathrm{h}^{\prime}=\mathrm{h} / 2$.

$=700 / 2$

$=350 \mathrm{~mm}$

$\mathrm{F}_{2}=1000 \times 9.81 \times 0.35 \times .8917$

$=3061.82 \mathrm{~N}$

$=312.11 \mathrm{kgf}$

Pressure acting on the side walls: $\mathrm{P}_{2}=\mathrm{F} / \mathrm{A}$

$$
=3061.82 /(0.35 \times 0.8917)
$$$$
=955.57 \mathrm{~N} / \mathrm{m}^{2}
$$

\section{$>$ Outlet}

Force acting on the outlet:

$\mathrm{F}_{3}=\rho \mathrm{gh}$ 'A.

$$
\begin{aligned}
& =1000 * 9.81 *(0.7 / 2) *(0.7 \mathrm{X} * 0.95) \\
& =2283.277 \mathrm{~N}
\end{aligned}
$$$$
=232.75 \mathrm{kgf}
$$

Pressure acting on the outlet:

$$
\mathrm{P}_{3}=\mathrm{F} / \mathrm{A} \text {. }
$$

$=2283.277 /(0.7 * 0.95)$

$$
=3.433 \mathrm{kN} / \mathrm{m}^{2}
$$

\section{Inlet}

Force acting on the inlet:

$$
\begin{aligned}
\mathrm{F}_{4} & =\rho g h ' A \quad \ldots \ldots \ldots \ldots \ldots \ldots \ldots . . \\
\mathrm{h}^{\prime} & =\mathrm{h} / 2 \ldots \ldots \ldots \ldots \ldots \ldots \ldots \\
& =700 / 2 \\
& =350 \mathrm{~mm} \\
\mathrm{~F}_{4} & =1000 * 9.81 *(0.350) *(0.8087 * 0.95) \\
& =2637.838 \mathrm{~N} \\
& =268.893 \mathrm{kgf}
\end{aligned}
$$

Pressure acting on the outlet:

$$
\mathrm{P}_{3}=\mathrm{F} / \mathrm{A}
$$

$$
=2637.838 /(0.8087 * 0.95)
$$$$
=3.433 \mathrm{kN} / \mathrm{m}^{2}
$$

$>$ Volume of water displaced by Top part $=$ Height $*$ Length *Width ....

$>$ Volume of the gas that can be stored $=$ Length $*$ Width *Height

$$
\begin{array}{rl} 
& =(0.95 * \\
0.95 * & * \\
& \mathrm{~m}^{3} \\
= & 0.37 \mathrm{~m}^{3} \\
= & 270 \text { litres }
\end{array}
$$

$>$ Bending Moment,

$$
\begin{aligned}
& \mathrm{M}=\mathrm{IS} 3370 \text { constant } * \text { Unit length } \\
& * \text { Volume of Bottom part }(\mathbf{1 . 1 3}) \\
& =0.077 * 1000 * 0.8^{3} \\
& =39.424 \mathrm{~kg}-\mathrm{m}
\end{aligned}
$$

Bending stress,

$$
\begin{aligned}
& \sigma=\mathrm{M} / \mathrm{Z}=\mathrm{M} /\left(\mathrm{bd}^{2} / 6\right) \\
\ldots \ldots \ldots \ldots \ldots \ldots \ldots \ldots \ldots & (\mathbf{1 . 1 3}) \\
= & 39.424 * 10 * 1000 * 6 /\left(1000 * 3^{2}\right)
\end{aligned}
$$

$=262.826 \mathrm{~N} / \mathrm{mm}^{2}$ which is less than strength of fiberglass $(75$ $\mathrm{kN} / \mathrm{mm}^{2}$ ).

\section{Bottom Part}

Material: Fibreglass, wood.

Thickness: $3 \mathrm{~mm}$.

Dimension: $0.8 \mathrm{~m}^{3}$.

Fig 1 shows the overall view of the bottom part. Fig 2 shows the fabrication process of the bottom part. Fig 3 shows CAD drawing of the bottom part. 


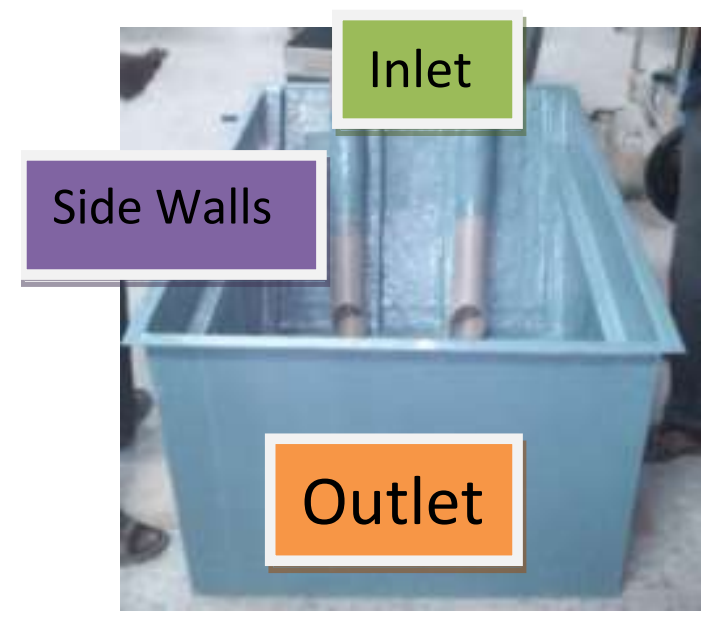

Fig 1: Overall view of the bottom part

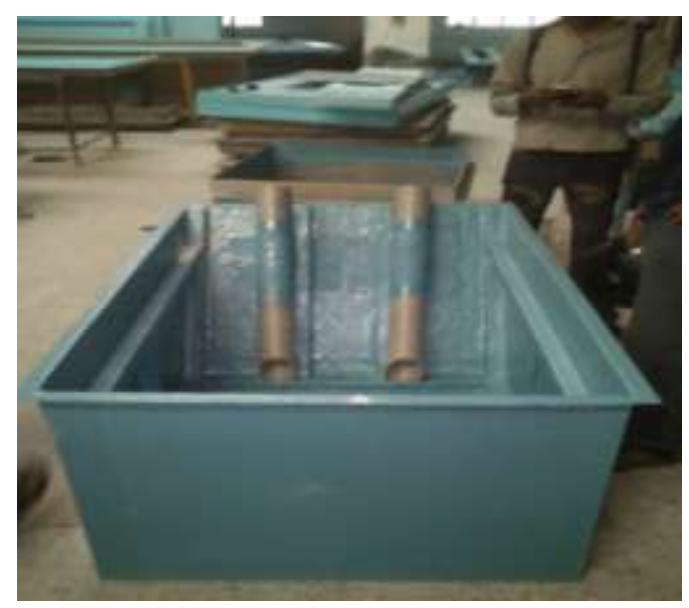

Fig 2: Fabrication process of bottom part
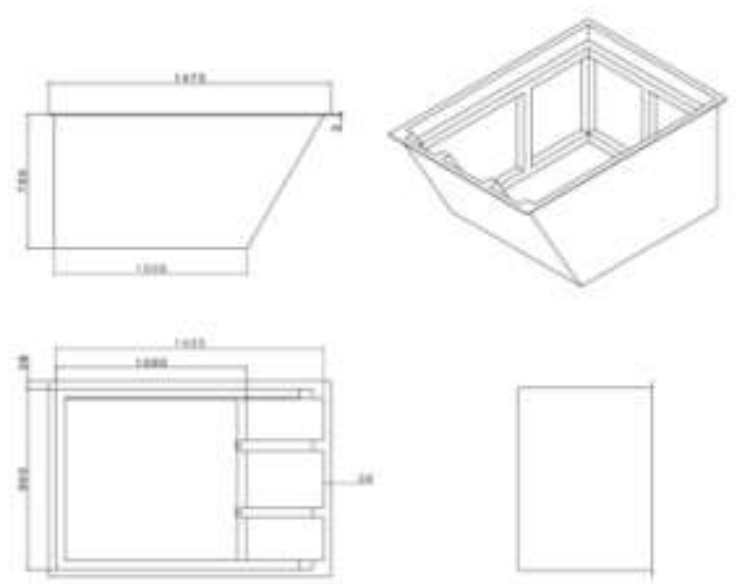

Fig 3: CAD drawing of the bottom part

\section{Fabrication Process:}

The steps in the fabrication of bottom part are as follows,

- Fibreglass sheets of $3 \mathrm{~mm}$ thickness are cut into the required shape as shown in the Fig 3.

- The fiberglass sheets are joined primarily with the use of quick bond as shown in the Fig 4 .
- The corners of the fiberglass sheets are now joined permanently with the help of Chopped strand mat laminate and Polyester resin. This gives strength to the corners. This is shown in the Fig 5

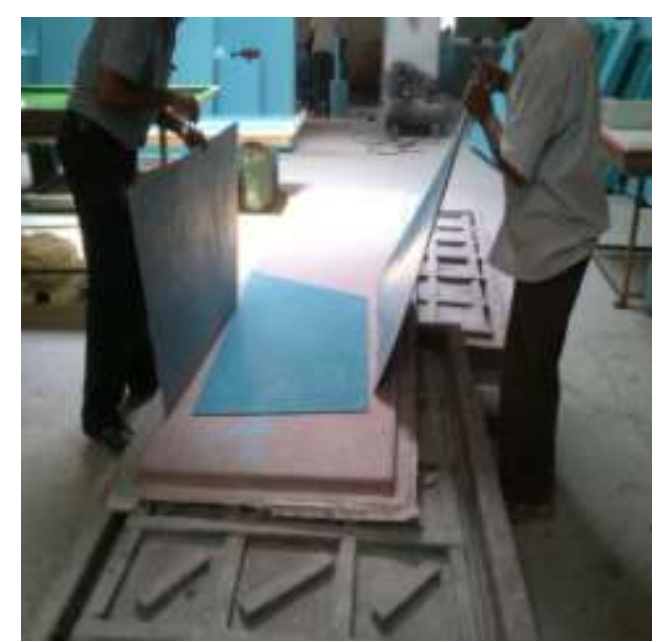

Fig 3. Usage of Fibreglass sheets for the fabrication of the part



Fig 4: Usage of the quick Bond for joining fiberglass sheets

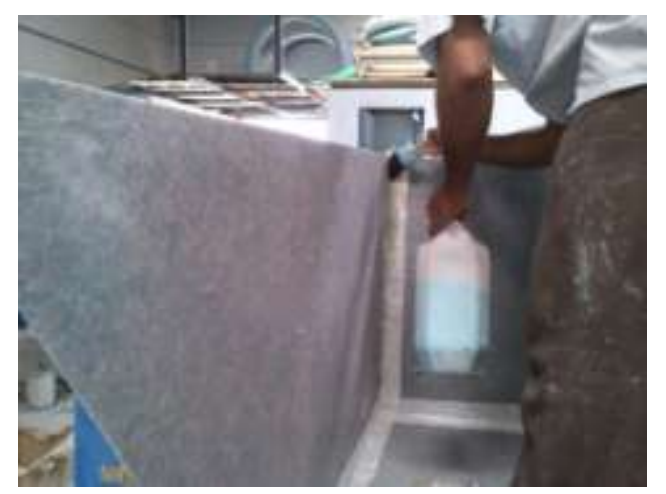

Fig 5: Usage of Chopped strand mat laminate and polyester resin for the permanent joint 


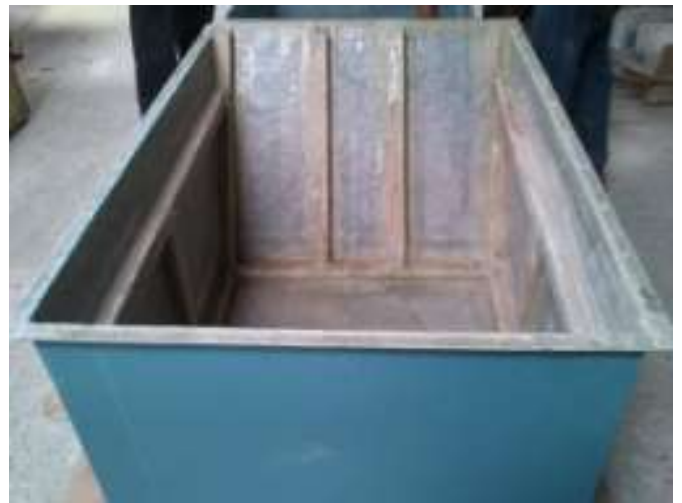

Fig 6: Usage of wooden rods as stiffeners

- After the edges are secured using the fibre wool and resin, wooden stiffness is provided. 2in X 2in wood rods are used as stiffeners along the body of the bottom part to increase the overall stiffness of the bottom part. This is shown in Fig 6 .

- $\quad$ Flanges are joined to increase the stiffness. It also helps for the top part to sit on the bottom part.

- An overflow valve is provided for the excess slurry to flow out. This is shown in Fig 7.

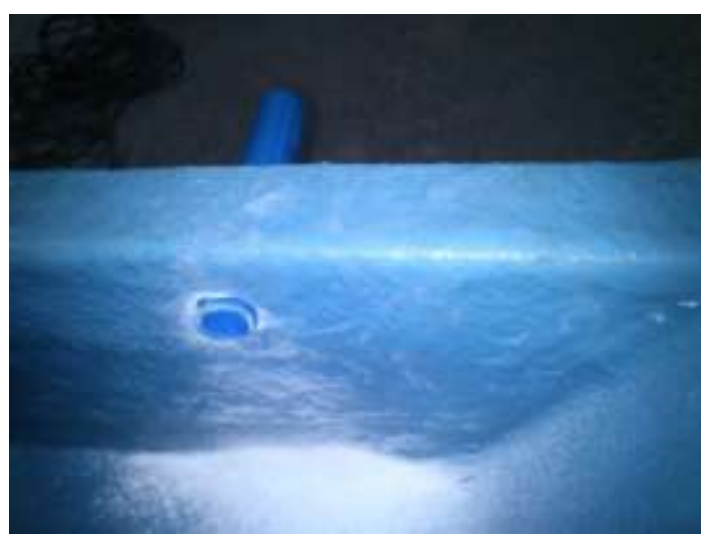

Fig 7: Incorporation of overflow valve for excess slurry to flow out



Fig 8: application of water repellant coating

- Water repelling coating and another layer of fiberglass coating is given and the final bottom part is ready. This is shown in Fig 8.

\section{Top Part}

Material: Fibre glass.

Thickness: $3 \mathrm{~mm}$.

Dimension: $0.5 \mathrm{~m}^{3}\left(0.26 \mathrm{~m}^{3}\right.$ for gas accumulation and $0.24 \mathrm{~m}^{3}$ for the placement of balloon)

It is depicted in the Fig 9. CAD drawing of the same Top part is shown in Fig 10.

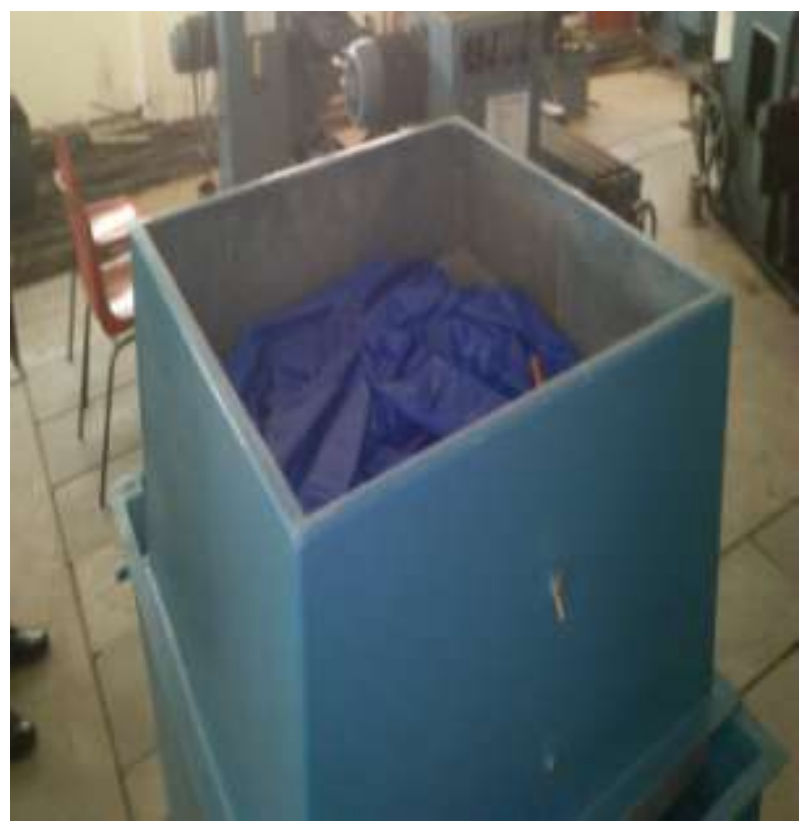

Fig 9: Top portion with the balloon
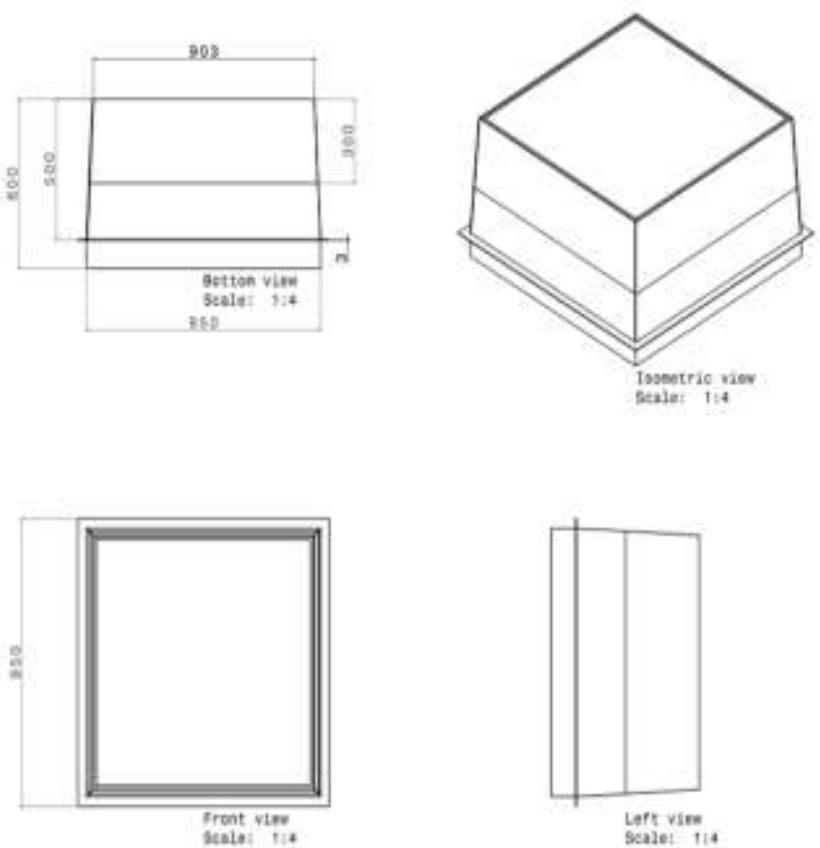

Fig 10: CAD drawing of the Top

Fabrication Process:

The steps in fabrication of top part are as follows,

- A mould of required dimensions is made using fiberglass. The mould is as shown in the Fig 11. 


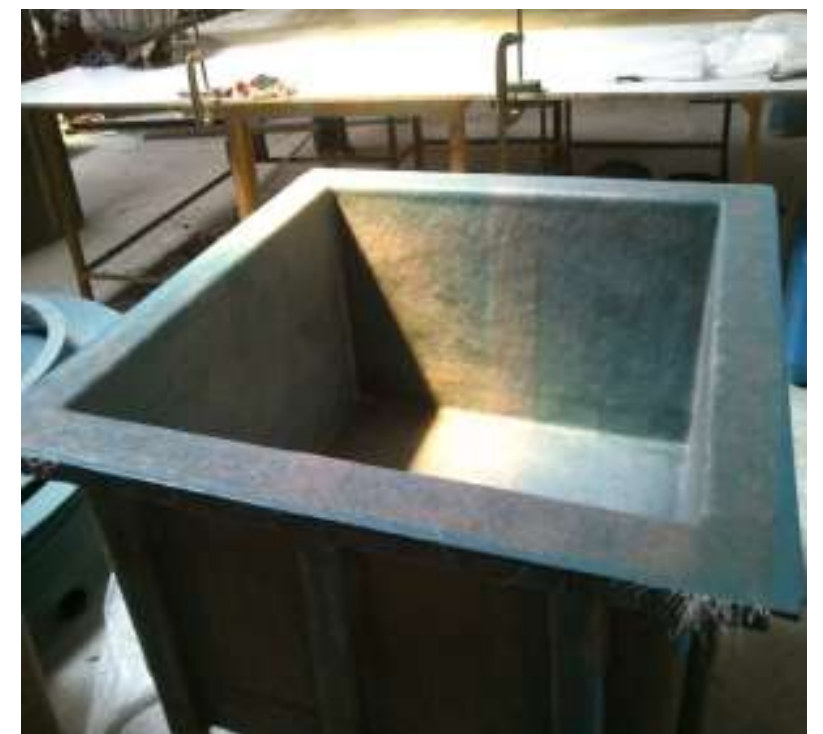

Fig 11: Mould for the fabrication of the top part

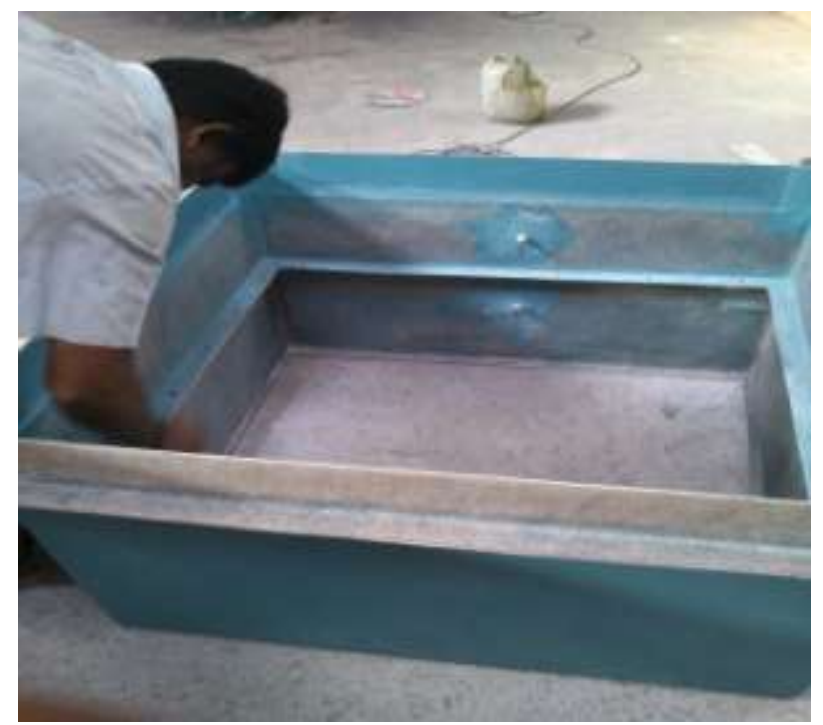

Fig 12. shows the valves and the flanges in the top part.

- A wax coating is applied on the mould and layers of Chopped Strand Mat Laminate are laid on the mould. Polyester resin is applied on the fiberglass.

- This process is continued till a thickness of $3 \mathrm{~mm}$ is reached.

- The part is allowed to cure for a certain amount of time.

- A flange of about $100 \mathrm{~mm}$ height is fixed to the top part using quick bond and permanently using layers of Chopped Strand Mat Laminate and polyester resin.

- A partition is given at a distance of $300 \mathrm{~mm}$ from the top of top part to hold the storage balloon.

- Holes are drilled in the top part so that the gas can be collected and stored in the balloon. Also valves are provided to tap out the stored gas.

- A fiberglass sheet of $3 \mathrm{~mm}$ thickness is provided so that it can be placed on top of the balloon to apply pressure required to tap the gas out.

- Some photos of the top part are shown in the pictures bellow.

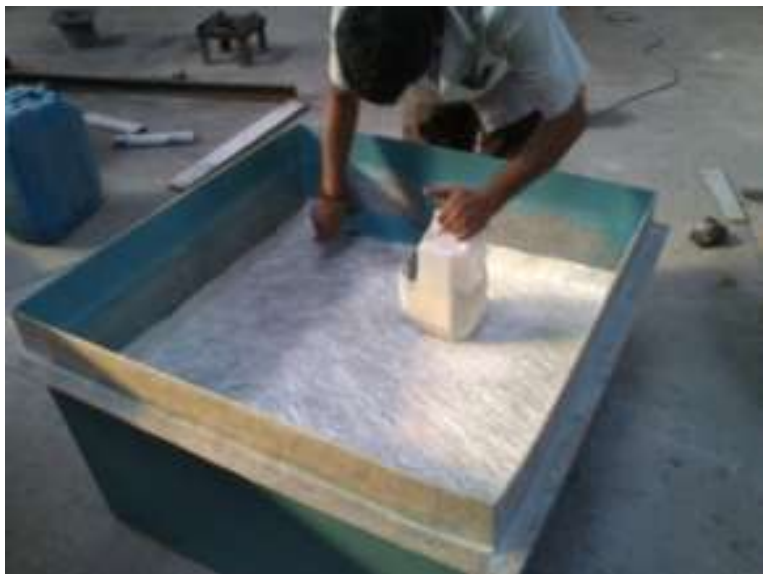

Fig 13. shows the partition in the top part.

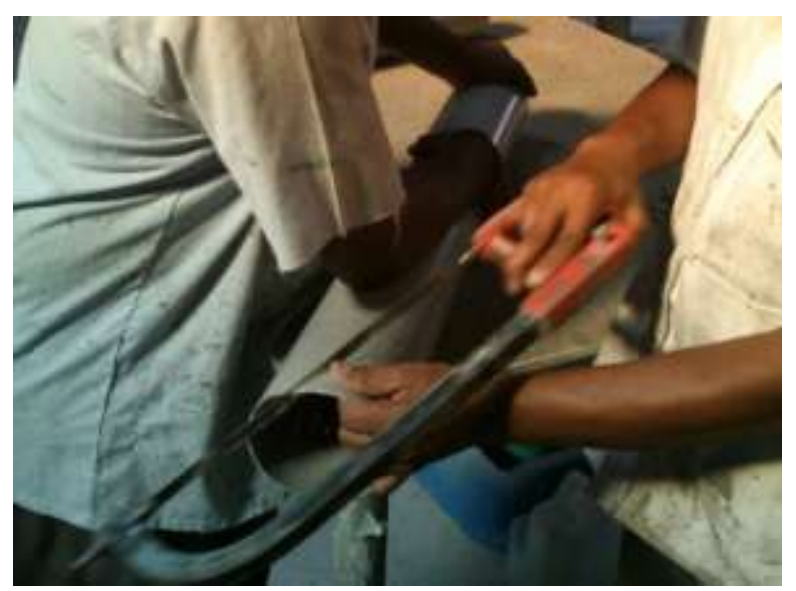

Fig 14: Fabrication of the inlet pipe

\section{Inlet pipe}

Material: P.V.C (Polyvinyl Chloride).

Dimension: $101.6 \mathrm{~mm}$.

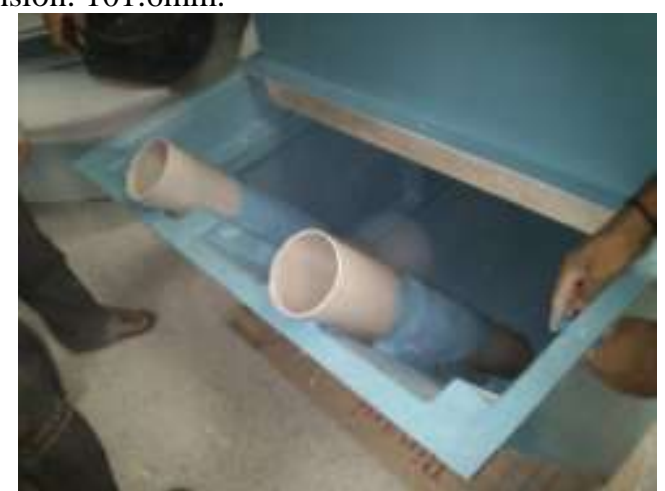

Fig 15: Incorporation of the inlet ppes to the bottom part

- The inlet pipe is cut at the edges at an angle of $45^{\circ}$.

- The pipe is fixed to the bottom part by applying a layer of fiberglass on it.

- Two pipes are provided for inlet of the same dimensions.

\section{Balloon}

Material: Polythene

Dimension: $0.95 \times 0.95 \mathrm{~m}^{2}$. 


\section{CATIA model}

- The balloon is the storage unit of the biogas plant.

- A polythene sheet is taken of required dimensions and is sealed at the corners by using a sealing machine.

- The balloon is sealed on all four corners four times so that the gas does not escape.

- The balloon has a pipe through which gas enters and exits the balloon.

\section{FINAL FABRICATED MODEL}

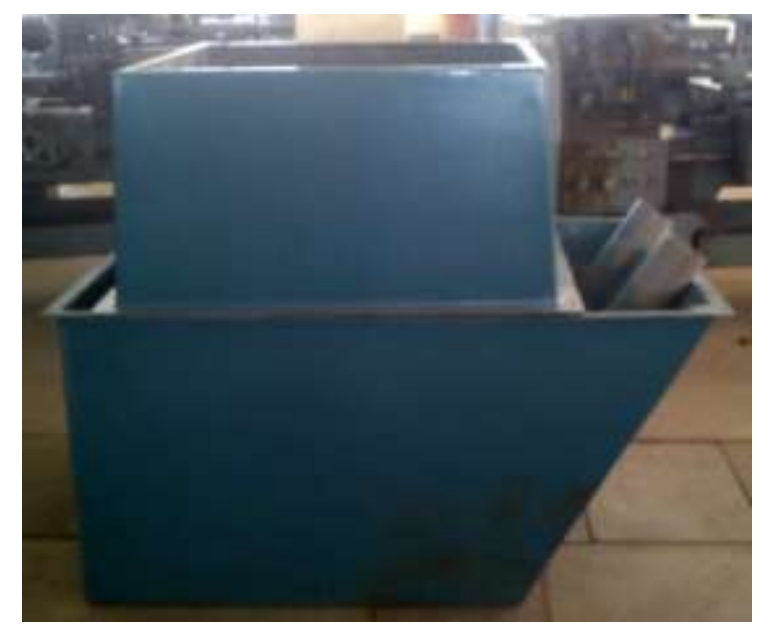

Fig 16: CATIA Model of the Digester



Fig 17: Overall view of the Digester

\section{EXPERIMENTAL DETAILS}

Experiment was carriedout on the fabricated model of the biodigester of capacity around 30 litres.

Slurry made out of cow manure and water was fed through the inlet until the digester is about $80 \%$ filled, and the slurry surface on both inlet and outlet did not have holes by which the air can pass into the digester. This was to create the anaerobic condition in the gas space inside the digester cavity. After the first filling, both the inlet and outlet valves were covered and gas valve to the gas holder was kept opened. In the first 20 days, the gas holder expanded with the produced gas volume. The first 20 days was the analysis phase of the biogas production and it was made to act as a batch type reactor. At the end of 20 days, the content of the gas holder was taken out as it did not burn due to the predominant amount of carbon dioxide. The next phase was started when the biodigester was fed periodically with slurry including kitchen and domestic waste from the M. S. Ramaiah Institute of Technology college cafeteria.

After the digester became operational for several weeks after the initial filling, the $\mathrm{pH}$ value had reached the stable level of 6.5 that remained constant during the period of experimentation. The temperature also was constant between 35-40 during the day and 25-30 during the night. Therefore, those two parameters were kept as the constants with respect to the model development. Based on the field data obtained, those two parameters did not fluctuate significantly in climate conditions of Bangalore .

\section{CONCLUSIONS}

Important advantages associated with the above mentioned design are:

$>$ Versatality Of Design and flexibility

$>$ Cost Effectiveness and Affordability

$>$ Strength as well as Durability

$>$ Aesthetics

$>$ Specialized Physical Properties

$>$ Versatility Of Design and flexibility

\section{VERSATALITY AND FREEDOM OF DESIGN}

Fiberglass and composites such as carbon fiber allows tooling, modeling, and fabrication into almost any shape or design. But there are few restrictions on color, finish, shape and size. This offers many solutions to architects and designers to allow their creativity to flow. If one can imagine it, he can most likely fabricate it out of fiberglass, composites, or carbon fiber.

\section{COST EFFECTIVENESS}

AND

\section{AFFORDABILITY}

Fiberglass and composites are very much affordable and gives cost effective solutions for almost all application, component and part. The costs of engineering and prototyping are relatively low in comparison with other manufacturing techniques and methods.

\section{STRENGTH AS WELL AS DURABILITY}

Fiberglass forms an attractive, lightweight, and flexible material. Composites such as carbon fiber can be even lighter and stronger. Fiberglass and composites have got one of the highest strength to weight ratio available for component manufacturing. Fiberglass is stronger than sheet metal or steel. Manufacturing parts from fiberglass gives strength directly into a finished product, much more compared to standard injection mold. The sleek, moulded finish of fiberglass components gives products an extremely finished and high tech appearance. 


\section{SPECIALIZED PROPERTIES OF FIBERGLASS}

Fiberglass is a dielectric. It means that it is non-conductive and RF transparent. This makes fiberglass ideal for applications where metal housings can affect electronic performance of a product or where electrically conductive metal housings can create safety hazard.

Fiberglass is chemically inert. This means that it will not react chemically with other materials.

\section{REFERENCES}

[1] Biogas Technology by Dr. Viresh kumargoud, Dr T.N Tulasidas and Er. H. Eshwarappa, published by regional biogas development and training cenrtre. Dept of Agricultural science, GKVK bangalore.

[2] Biogas Technology. By B.T.Nijaguna

[3] H.C.Nagaraju(1981),M Sc thesis submitted to the university of agricultural sciences,Bangalore

[4] Ariane Van Buren(1979),A Chinese Biogas Manual.

[5] C.R.Das and S.D.Ghatnekar (1979),Paper presented at research planning workshop on Energy for rural development,IIM,Ahmedabad Dec 27-29 1979

[6] Plug flow digester for biogas generation from leaf biomass,Published by Elsevier Science Ltd.,By K.S.Jagadish,H.N.Chanakya,P.rajabapaiah,V anad ASTRA,Indian Institute of science ,Bangalore

[7] Prediction of the fixed-bed reactor behavior using dispersion and plug flow models with different kinetics for immobilised enzyme,y Carlos R Carrara,Enrique J Mammarella and Amelia C Rubiolo,Science direct

[8] Renewable Energy sources and Emerging Technologies,By Kothari Et Al.

[9] Raven,R.P.J.M,Gregersen,K.H.Biogas plants in Denmark:success and setbacks

[10] Amigun. B, Von Blottnitz, Capital cost prediction for biogas installations in Africa

[11] Parawira,W.Biogas technolo in sub-Saharan Africa: Status ,Propects and constraints

[12] Omer.A.M,Fadalla .Y.,Biogas energy technogy in Sudan 